\title{
Good Governance as a Catalyst to Nation Building through Economic Growth and Development of Local Government Areas in Nigeria
}

\author{
Musa Muhammad Mahuta ${ }^{1}$, Danjuma Abdullahi ${ }^{2}$ \& Prof.C.U Aliyu ${ }^{3}$ \\ Department Of Local Government Studies, Waziri Umaru Federal Polytechnic, Birnin Kebbi. \\ Department Of Public Administration Waziri Umaru Federal Polytechnic, Birnin Kebbi. \\ Department Of Economics, Usmanu Danfodio University, Sokoto
}

\begin{abstract}
The Local Government Administration is a process of manipulating resources at the grassroots level in order to meet up the need of local communities that form such geographical entities for both economic growth and improvement of the quality of life of the rural populace. Generally, Local Government exists in order to provide avenues for effective Local participation, efficient service delivery and effective mobilization of local resources. The paper relied on secondary data, such as journals pamphlets, annual publications and text books, the findings revealed that inherent practices in local government negate growth and development and the paper recommends good leadership practices such as accountability, transparency, effective leadership and rule of law.
\end{abstract}

\section{Introduction}

There is much concern for the concept of good governance in both national and international scenes because of its direct bearing on economic development and nation building. The concept of good governance has been seen from various perspectives such as perspective of human rights, political perspective, economic perspective, etc. in our context, we shall limit our discussion only on political and economic perspectives form political perspective, good governance has been defined as:-

'The exercise of economic, political and administrative authority to manage a country's affairs at all levels in a manner that is participatory, transparent and accountable.

From economic perspective, good governance "concerns norms of behaviour that help ensure that governments actually deliver to their citizens what they said they will deliver."

It is apparently clear that both the definitions are concerned primarily with manner, strategy and modality of effective as well as efficient and judicious management and utilization of both material and human resources in a just, transparent and accountable manner for the realization of the aspiration of the people.

\section{ECONOMIC GROWTH AND DEVELOPMENT}

Economic growth can be defined as increase in an economy's real level of output over time. It is absolute increases in economic parameters such as Gross National Product, percapita, etc ${ }^{3}$ On the other hand, economic development is seen as a multi-dimensional process involving changes in structures, attitudes and institutions as well as acceleration of economic growth, reduction of inequality and eradication of absolute poverty.

\section{LOCAL GOVERNMENT}

This refers to a political and administrative unit that is empowered by law to administer a specified locality". The main reason for the creation of this third tier of government are amongst other things, to bring government very adjacent to people, administrative conveniences, fostering development, preserving heritage and common interest of people etc. (Agbakoba and Ogbonna, 2004).

Therefore, we can infer from the definition that, local government is the lower level of government that is legally distinct and has power to raise revenue and undertake assigned responsibilities under a leadership that is elected and answerable to the local population for the transformation of various communities into effective socio-economic and political advanced structures for a national development.

\section{PROBLEMS MILITATING AGAINST ECONOMIC GROWTH AND DEVELOPMENT OF LOCAL GOVENRMENT AREAS}

There are quite a sizeable number of factors inhibiting growth and development of the grassroots at the local government level. These problems emanate significantly as a result of absence of proper mechanism that will allow good governance to prevail. Some of the problems can be unfolded as follows: 


\section{UN-SKILLED HUMAN RESOURCES}

It is undoubtedly a fact that human resources are ingredient for effective growth and national development. In most Local Government Areas. It is very common to find that the leaders/officials running the affairs of people are lacking pre-requisite administrative skills to deliver the dividend of good governance (Agbakoba and Ogbonna, 2004). The minimum qualification set out by the Consitution for election into Local Government Council is Secondary Certificate which is too low for the challenges in the Local Government Affairs. This problem poses certain constraints to the healthy growth of the Local Government Areas as well as national building because the necessary technical and scientific procedures are absent. To say the least, Local Government Areas serve just as a dumping grounds for unskilled and bunch of illiterates.

\section{WIDE SPREAD OF CORRUPTION AND OTHER FRAUDULENT PRACTICES.}

The cankerworm of corruption and other fraudulent practices has permeated all nook and corners of most Local Government Areas. Most people are engulfed in the problem of corruption has eaten deep into the moral fabric of our society and has become so passive and intractable. There is a lot of looting, embezzlement and squandering of public properties/funds and no proper control mechanism exists to curb the menace.

Several reasons have been identified by scholars (e.g Ajakaiye, 2000, Obadan 2002, Dantama and Aliyu 2004, etc. for the unsavoury situation such as amongst other factors, too much pressure of societal expectations on the leaders, lack of proper accounting procedure, lack of accountability and transparency etc.

\section{LACK OF POPULAR PARTICIPATION OF STAKEHOLDERS IN DECISIONS AND POLICES FOR NATION BUILDING.}

For healthy growth and progress of Local Government Areas and national development, there is the need for consultation with various stakeholders ranging from the general public to NGOs, CBOS, etc. Unfortunately, most Local Governments in Nigeria are rural based, thus, making participation by citizinery very limited. Antoehr factor which aggravated absence or little participation as rightly observe by Agbakoba and Ogbonna (2004), was the impact of the prevalence of long period of military rule in the nation which almost demoralized and killed the psycle of the civil societies especially at the grassroots level.

Similarly, lack of adequate information for the civil societies to operate, coupled with inadequate backup laws for civil socities to participate in governance, also limit the activities of civil societies decision making processes at the Local Government Areas.

\section{PROBLEMS OF CONFLICTING LAW}

It is a common knowledge that the 1999 constitution has created legal problems for Local Governments to assume their rightful role as the third-tier of government (Agbakoba and Ogbonna, 2004), in the constitution, Local Governments are relegated to both the State and Federal Governments. The local government have to depend on states for allocation via what is called joint State Local Government Account. In most cases, the local government are not given adequate funds to cater for the needs of their populace. This lack of fiscal autonomy in allocation of funds and sometimes even in sources of revenue (such as taxes, etc) poses a lot of problem to the Local Government.

As observed by Mohammed and Tafida (2002), there is a serious conflict for the Local Government as the State Governments have the power to determine the tenure or Local Government Councils and in the area of finance there grant are disbursed from the federation account.

\section{ROLE OF GOOD GOVERNANCE TOWARDS GRASSROOTS DEVELOPMENT IN LOCAL GOVERNMENT AREAS AND NATION BUILDING.}

Good governance is a catalyst towards growth and development of grassroots at Local Government levels through the following:-

\section{GRASSROOTS PARTICIPATION AND BOTTOM-TOP APPROCHES IN DECISION MAKING:}

Good governance ensures grassroots participation in the affairs of the local governments. As suggested by Aliyu and Dogondaji (2008), good governance should be brought to bear on all facets of administration such as planning, controlling and budgeting. Generally, good governance will lead to provision of social services needed by the people which will improve their socio-economic well-being (Omebije 2006).

\section{PROVISION OF ENABLING ENVIRONMENT FOR PEOPLE TO ENGAGE IN ECONOMIC ACTIVITIES}

Through good governance, people at the Local Government level can be provide with opportunities in the form of job creation, infrastructural facilities, etc. These opportunities can of developmental project s/contracts. As observed by Aliyu and Dogondaji (2008), procurements and award of contracts at Local 
Government level are subjected to high risk of corruption and mismanagement. Therefore, the public should complement government accountability mechanism. Therefore, this can be done through due processes, in order to improve bidding process so that contracts can be properly awarded and monitored.

\section{Women Empowerment}

The place of women in the overall development of the society can not be over emphasized (Agbakoba and Ogbonna, 2004). But, unfortunately, women are yet to be fully integrated into economic and political spheres at grassroots level while some of the reasons for hti smarginalization are cultural or religious in nature, some are mainly due to ignorance. Therefore, through good governance women ca have access to education, credit facilities, better health services, etc. Therefore, where women are properly empowered there is likelihood that they will contribute their quota to economic development and nation building as well.

\section{Conclusion}

So far in this paper, we have defined some terms such as good governance, economic growth and development and local government. We have also examined the problems bedeviling local government areas. Moreover, we also looked at the role of good governance towards grassroots development. We can conclude at this juncture that, if the principles of good governance are applied in local governments, there will be high accelerated growth and development within the society as well as effective nation building.

\section{Reference}

[1]. Agbakoba, O. and Ogbonna, H., (2004) Local Government Administration and Development in Nigeria; A Capacity Building Manual, HURILAWS, Apapa, Lagos, Nigeria.

[2]. Dantama, Y.U and Aliyu, C.U. (2004) The Role of Ethics and Morality in Managing the Nigerian Economy in the $21^{\text {st }}$ Century in Aliyu, C.U and Abdullahi, A.S. Issues in Economics Vol. 1. Dept. of Economics, UDU Sokoto, Pp. 47-56.

[3]. Ajakaiye, O. (2000) "Problems of Public Policy Implementation in Nigeria". A paper presented to the NACCIMA/CIPE Workshop on Public Policy and Programme Implementation.

[4]. Obadan, M.I; et al (2002) "Democratic Governance and the Imperatives of effective planning and budgeting in a Democratic are setting NCEMA, Ibadan.

[5]. Kebbi State Government (2009) Draft vision 2020 Document Prepared by State Stakeholders Development Committee, Kebbi State, Nigeria.

[6]. Uremadu, S.O. (2002) Budgeting and Financial Management in the Public Sector: The Nigerian Experience, Abuja Journal of Administration and Management, Vol. 1 No 2, pp 50-67.

[7]. Muhammed I.A and Tafida, A.D (2002) State-Local Government relation in Nigeria 1999-2002, in Journal of Research and Development in Africa, vol 1 No. 2, University of Abuja, Nigeria, Pp 99-111.

[8]. Aliyu C.U and Abubakar, M (2004) A review of Nigeria's Economic Development under Globalization: Experience and Prospects in Issues in Economic Vol. 1, Department of Economics, UDUS, PP1-18.

[9]. Todan, M.P. (1977) Economic for a Developing World, Longman, London, UK.

[10]. Aliero, H.M, Muhammad B.A.S Maishanu, M. M, (2008) Towards Effective Budgetary Control in Local Governments: selected texts; Pentagram Consultants, Sokoto, Nigeria Pp. 18-33. 